\title{
Biografia zza przyłbicy. Kazimiera Iłłakowiczówna według Joanny Kuciel-Frydryszak ${ }^{1}$
}

Lucyna Marzec

TEKSTY DRUGIE 2019, NR 1, S. 181-194

DOI: 10.18318/td.2019.1.11 | ORCID: 0000-0001-6478-3997

Tła. Opowieść o Kazimierze Iłłakowiczównie Joanny Kuciel1 -Frydryszak sytuuje się gdzieś obok nowej humanistyki, poza dyskusjami wokół polityki i ideologii narracji historycznych, form pamięci/zapomnienia, etyki i tabu pisarstwa intymistycznego, w końcu (najstarszego, ale odświeżonego) problemu relacji życia i literatury, przekładania bio na tekst. Właśnie owe modalne (a przez to gatunkowe) kwestie pisania biografii po śmierci i powrocie autora; po końcu metafizyki obecności i wraz $\mathrm{z}$ dowartościowaniem doświadczeń immersji oraz praktyk rekonstrukcji; po końcu wielkich narracji i w trakcie ekspansji mikronarracji; są razem wzięte silnym magnesem, przyciągającym do refleksji nad biografią i tworzenia biografii oraz metabiografii - jak Milczaca kobieta $^{2}$ Janet Malcolm czy Ślady obecności. Poszukiwanie Ireny

1 Recenzja książki: J. Kuciel-Frydryszak Iłła. Opowieść o Kazimierze Iłakowiczównie, Marginesy, Warszawa 2017.

2 J.Malcolm Milcząca kobieta. Sylvia Plath i Ted Hughes, przeł. M. Michałowska, Zysk i S-ka, Poznań 1998.
Lucyna Marzec - dr, adiunkt Instytutu Filologii Polskiej UAM, redaktorka "Czasu Kultury," członkini Rady Naukowej Interdyscyplinarnego Centrum Badań Płci Kulturowej UAM. Edytorka Listów Kazimiery Iłłakowiczówny do siostry Barbary Czerwijowskiej z lat 1948-1959 (2014). Publikuje artykuły z zakresu biografistyki, krytyki feministycznej i życia literackiego XX wieku. Kontakt: lucyna.marzec@amu. edu.pl 
Szelburg ${ }^{3}$ Anny Marchewki. Równorzędny status biografki/biografa wobec bohaterki/bohatera opowieści i narracja skupiona na opowieści o poszukiwaniu, a nie rezultatach kwerend to nie tyle wynik emancypacji paratekstu, ile lekcji postmodernizmu (Papuga Flauberta Juliana Barnesa) i poststrukturalizmu (O pisarstwie historycznym ${ }^{4}$ Haydena White'a), i nie zawsze przyjmuje formę narracji konfesyjnej (jak w przypadku mistrzowskiego Guzika Puszkina ${ }^{5}$ Sereny Vitale). Co jednak istotne, granice narracji biograficznych (a to nie zmieniło się od czasów klasycznej monografii Marii Jasińskiej6) nadal przebiegają na linii naukowości i literackości, a ich najdrażliwszym punktem jest referencjalność. Narzucającym się przykładem jest podwójna - naukowa i literacka - praca wokół postaci Marii Komornickiej/Piotra Własta, której dokonały dwie pisarki-badaczki: Izabela Filipiak (Obszary odmienności; Księga Em) i Brygida Helbig-Mischewski (Stracona bogini; Inna od siebie). Świadczy ona nie tylko o fascynacji biografią konkretnej osoby, ale przede wszystkim o gatunkowych różnicach nie do podważenia oraz pisarskich potrzebach, których nie da się pogodzić w obrębie jednego gatunku'.

Książka Joanny Kuciel-Frydryszak nie mieści się też w rejonie reporterstwa historycznego, choć przez Opowieść przebija reporterski warsztat (autorka jest dziennikarką) i właśnie reportaż biograficzny jawi się obecnie jako dominujący gatunek biografistyki, stanowiący kompromisowe rozwiązanie problemów cudzo-życio-pisania. Kompromisowość reportaży biograficznych polega na tym, że podtrzymują referencjalny, dokumentarny status narracji przy zachowaniu literackich środków kompozycji, montażu, stylizacji: jest w nich miejsce na niedomówienia, znaczące milczenie, wybiórczość, wieloznaczność, efekty dyskrecji, troski, odzyskiwania, odbrązawiania, rewizji, skandalu. To właśnie reportaż wywołuje największe zainteresowanie czytelnicze i twórcze - w ostatnich latach znacznie rzadziej powstają typowe dla XX wieku biografie literackie pisane przez pisarki/pisarzy: prawdopodobnie ich czas już przeminął. Zarazem jednak reportaże wywołują (i chcą wywoływać) kwestie prawne i etyczne, których unikać mogła i może zawieszająca pakt

3 A. Marchewka Ślady obecności. Poszukiwanie Ireny Szelburg, Dodoeditor, Kraków 2014.

4 H. White Proza historyczna, przeł. R. Borysławski (i inni), red. E. Domańska, Universitas, Kraków 2009.

5 S. Vitale Guzik Puszkina, przeł. S. Kasprzysiak, Muza, Warszawa 2005.

6 M. Jasińska Zagadnienie biografii literackiej, Łódzkie Towarzystwo Naukowe, Łódź 1967.

7 Zob. G. Matuszek Strq̨cona bogini - Inna od siebie, "Teksty Drugie” 2017 nr 5, s. 209-218. 
referencjalny literacka biografia. Kompromisowość na poziomie modalności służy bezkompromisowym praktykom dyskursywnym i intensywnym reakcjom czytelniczym - jak w przypadku Oskarżonej Wiery Gran Agaty Tuszyńskiej czy Kapuścińskiego non-fiction Artura Domosławskiego.

Rewersem reportaży historycznych jest nurt biografii ,archiwistycznych”, szczegółowo analizujących niemal każdą notkę prasową i notatkę w brulionie pozostawioną w pisarskim archiwum. Wielotomowe monografie ujawniają zaangażowanie i świadomość teoretyczną biografów, ale stawiają swoim czytelnikom spore wymagania bliskiej autorce/autorowi naukowej dociekliwości. Z opowieści biograficznej, szytej według zasad literatury, przenoszą biografistykę w rejony pisania akademickiego, w którym króluje komentarz i metakomentarz, efekt przykładnego warsztatu, zdolności analitycznych, naukowego dystansu. Książka Kuciel-Frydryszak nie jest ani pracą pisaną na stopień, ani reportażowym „świadectwem prawdy”, ani literacką biografią korzystającą z praw fikcjonalności. Ciąży w kierunku znarratywizowanej monografii typu „życie i twórczość", chociaż poezję Iłły traktuje na równi z różnej kategorii dokumentami ego. Nie jest to jednak „biografia poetki” (jak w przypadku Lilki Kossak Anny Nasiłowskiej) - interpretacyjne prace literaturoznawcze Kuciel-Frydryszak pomija milczeniem; ani biografia kontekstowa (jak w Mikołajskiej. Teatrze i PRL Joanny Krakowskiej), ponieważ nie interpretuje na nowo wiedzy o tym wycinku historii, który wiąże się z życiem autorki Stowika litewskiego. Opowieść ma na celu przedstawić „biografię jednostki na tle dziejów", na plan pierwszy wysuwając psychologię bohaterki (oraz jej najbliższych). I właśnie to połączenie stanowi o sile i słabości Itły. Opowieści o Kazimierze Itłakowiczównie.

Niepodważalnym osiągnięciem Kuciel-Frydryszak jest naszkicowanie kalendarium życia Iłłakowiczówny. Tej żmudnej i czasochłonnej pracy dokumentacyjnej nikt dotąd nie wykonał i znarratywizowana wersja autorki Itty jest pierwszą propozycją rozpisania w porządku czasowym życia poetki. Poprzednicy biografki nie byli tak szczegółowi (do tej pory najbardziej skrupulatną wersję zaproponował Józef Ratajczak ${ }^{8}$ ) i być nie mogli z kilku powodów. Iłłakowiczówna zastrzegła, że jej archiwum, zdeponowane w Bibliotece PAN w Kórniku, będzie dostępne w celach naukowych 30 lat po jej śmierci (co nastąpiło stosunkowo niedawno, tj. w 2003 roku). Autobiograficzne

8 J. Ratajczak Lekcje u Iłłakowiczówny. Szkice, wspomnienia, listy i wiersze, Krajowa Agencja Wydawnicza, Poznań 1986; tegoż Twarze Iłły [wstęp], w: K. Iłłakowiczówna Poezje zebrane, t. 1, zebr. J. Biesiada, A. Żurawska-Włoszczyńska, Algo, Toruń 1998, s. 5-19. 
tomy poetki, Niewczesne wynurzania (1958) i Trazymeński zając (1969), mają co prawda charakter wspomnieniowy (bliski narracyjno-ontologicznej perspektywy „świadectwa” w „autobiograficznym trójkącie” Małgorzaty Czermińskiej), ale są raczej świadectwem pracy osobistej i kulturowej pamięci i zapomnienia oraz cenzury i autocenzury. Wiele mówią o kreacji narratorki, maskach autobiograficznych i szczególnym, indywidualnym doświadczeniu historii, nie są najlepszymi drogowskazami w zakresie dat, nazwisk i miejsc. Podobnie ma się rzecz z hasłami w słownikach biobibliograficznych, nawet tymi zaaprobowanymi przez poetkę - zawsze znajdują się w nich pewne przesunięcia i różnice, które nie pozwalają na precyzję. Poza tym Iłłakowiczówna nie pozostawiła niepublikowanych wspomnień, pamiętnika czy dziennika - form ułatwiających zadanie biografa. Dla równowagi poetka szczegółowo opracowała swoje archiwum, składające się przede wszystkim z korespondencji, które jest dla Opowieści najważniejszym punktem odniesienia. Kuciel-Frydryszak jako pierwsza pośród licznych przeglądających teki Iłłakowiczówny w Bibliotece Kórnickiej postawiła na ogląd całości. Sam fakt zakończenia prac - tj. umiejętnej selekcji ogromu materiału i znarratywizowania wyników badań jest sukcesem, zważywszy na to, ile pisarzy i pisarek nie ma jeszcze swoich biografii, bo opracowania ich spuścizny wymagają szeroko zakrojonych działań (jak w przypadku Witkacego i wieloletniej pracy zespołu badawczego Janusza Deglera $\left.{ }^{10}\right)$. Piszę te słowa „z wnętrza” kórnickiego archiwum, ponieważ opracowuję je do swoich celów i zdaję sobie sprawę z wyzwania, którego podjęła się autorka Opowieści. Z tych samych powodów mogę zrekonstruować metodę pracy w archiwum, którą przyjęła Kuciel-Frydryszak: to metoda synekdochicznego sondowania, czyli potraktowania materiału wybiórczo, z gotowym planem działania i konkretnymi pytaniami,

9 Oprócz badaczy innych spuścizn (m.in. Juliana Tuwima, Marii Dąbrowskiej, Anny Kowalskiej, Willama Horzycy, Jana Henryka Rosena), dla których archiwum Iłłakowiczówny miało charakter kontekstowy oraz osób, które pisały o Iłłakowiczównie prace dyplomowe (najczęściej na poznańskiej polonistyce), szczególnie dogłębnej kwerendy dokonały: Roksana Jędrzejowska-Wróbel, autorka niepublikowanej rozprawy doktorskiej Powojenna korespondencja Kazimiery Iłłakowiczówny z pisarkami z aneksem listów, komentarzem edytorskim i zarysem kalendarium (obronionej na Uniwersytecie Gdańskim w 2005 roku), zob. R. Jędrzejowska-Wróbel Korespondencja Kazimiery Hłłakowiczówny z Mariq̨ Dąbrowskq, Pamiętnik Biblioteki Kórnickiej 2005 nr 27, s. 189-205; oraz Monika Chuda (zob. tejże Z adresownika poetki. Śladami listów Kazimiery Iłłakowiczówny w bibliotekach polskich, Biblioteka $2010 \mathrm{nr} 14$ (23), s. 201-213.

Zob. J. Degler Witkacego portret wielokrotny: szkice i materiały do biografii, PIW, Warszawa 2009; Kronika życia i twórczości Stanisława Ignacego Witkiewicza, opr. J. Degler, A. Micińska, S. Okołowicz, T. Pawlak, PIW, Warszawa 2017. 
które się stawia konkretnym tekom (i najważniejszym korespondentom). Nie jest ona obca najwybitniejszym: podobnie pracuje Arlette Farge ${ }^{11}$, przestrzegając przed zgubną dla pracy historycznej skłonnością do wchłonięcia w archiwum. System wyboru materiału archiwalnego jest konieczny przy wielkich tematach badawczych (Farge wspomina o kryminalnym Paryżu XIX wieku), ale Opowieść jest dowodem na skuteczność tej praktyki w przypadku stworzenia portretu bohaterki biografii, który nie wyróżnia się od obrazu Iłłakowiczówny taką, jaką ją znamy. To ogląd panoramiczny: dziewczynki na utrzymaniu arystokratki, nieszczęśliwej, zbuntowanej dziewczyny, siostry miłosierdzia na froncie I wojny światowej, oddanej pracy urzędniczce i patriotce, obrończyni słabszych (służących i szykanowanego Tuwima), zaprzysiężonej marszałkowi dyplomatki, biedującej na emigracji nauczycielce języków, dyskryminowanej tłumaczce, w końcu starzejącej się w chorobie damie, zbierającej żniwa w trudnych warunkach. Kuciel-Frydryszak scala twarze Iłły i daje biografię, która popularyzuje i przybliża tę nieco zapomnianą, jeśli nie zaniedbaną postać. Można, rzecz jasna, dodawać więcej szczegółów do tych portretów, doprecyzowywać i nanosić korekty do niektórych ustaleń Kuciel-Frydryszak - „archiwistyczna” biografia Iłłakowiczówny jest projektem otwartym - i zapewne sensownym, ale niewnoszącym wiele dla metody, którą obrała autorka Itty...

Opowieść jest tak skonstruowana, że,snuje się sama” według tradycyjnego i sprawdzonego schematu „od urodzenia do śmierci”, a książka napisana jest czystą i życzliwą odbiorcy polszczyzną stylu zerowego, ukrywającą swą narratorkę i jej źródła. Reguły tej opowieści i sposób argumentacji przypominają metodę Jamesa L. Clifforda, ujęte w metaforze „Od kamyków do mozaiki”"2. Narrację Kuciel-Frydryszak wspierają parafrazy wcześniejszych biografii Iłły (wspomnianego Ratajczaka i Łucji Danielewskiej¹3) i kilka artykułów na jej temat (najczęściej o charakterze wspomnieniowym, autorka wybiórczo korzysta z przekraczającej kilkaset pozycji bibliografii przedmiotowej o poetce,

11 A. Farge Allure of the Archives, przeł. T. Scott-Railton, New Haven-London 2013.

12 J.L. Clifford Od kamyków do mozaiki. Zagadnienia biografii literackiej, przeł. A. Mysłowska, Czytelnik, Warszawa 1978. Anita Całek w swej typologii narracji biografistycznej powołując się na Clifforda szkicuje figurę narratora-mozaicysty, która także odpowiada konstrukcji Opowieści. Mnie interesuje podobieństwo warsztatu, na który w równej mierze składa się rygorystyczna praca, co zdanie na przypadek. Zob. A. Całek Biografia naukowa: od koncepcji do narracji. Interdyscyplinarność, teorie, metody badawcze, Wydawnictwo UJ, Kraków 2013, s. 34-39. 
zbudowanej przez Jacka Biesiadę i Aleksandrę Żurawską-Włoszczyńską ${ }^{14}$ ), wypowiedzi nielicznych rozmówców, autobiograficzne eseje samej poetki oraz obszerne cytaty z listów i poezji.

Podobnie jak w metodzie mozaikowej, tylko wybrane materiały zostają przez narratorkę wyodrębnione z jednolitej opowieści; najjaskrawszymi elementami układanki są ujawnione listy jako odkrycia archiwistyczne, autorka przy tym podobnie traktuje liryki Iłłakowiczówny - są rozstrzygającym materiałem argumentacyjnym. W tych miejscach tekstu ujawnia się główny temat książki oraz intensyfikuje się obecność narratorki, która zwraca uwagę na znalezione w archiwum materiały czy strofy w tomach poetyckich - zadaje retoryczne pytania („Czy była szczęśliwa?”) i daje odpowiedzi na pytania zadane implicytnie.Teza pracy, będąca jednocześnie diagnozą psychologiczną, brzmi mniej więcej tak, że Iłłakowiczówna była kobiecym geniuszem poetyckim, osobą pokrzywdzoną psychologicznie i społecznie przez skazę nieślubnego pochodzenia oraz melancholiczką, gnębioną wyrzutami sumienia za nastoletni bunt wobec przybranej matki. Do tych czynników psychologicznych przychodzi wpisany w historię wzór życia: „Życie Iłłakowiczówny ma kształt sinusoidy, fazy trudniejsze poprzedzają dramatyczne zwroty, a okresy pomyślności wynikają z pozytywnych splotów okoliczności, których poetka się już nie spodziewa. O tym, czy jest na fali, czy pod nią, decydują zdarzenia historyczne wpisane w życiorys, sam w sobie już bardzo skomplikowany"15. Konsekwencją tej wizji, zakładającej, że człowiek ma ograniczoną sprawczość i raczej poddaje się procesom historycznym, niż je współtworzy, i podobnie rzecz się ma ze światem wewnętrznym, psychiką - wytwarza się za mło$\mathrm{du}$, a potem noszona jakby niezależnie od woli osoby i tylko modyfikowana silniejszymi wstrząsami - jest statyczna wizja ludzkiego istnienia i ujęcie stroniące od diagnoz społeczno-kulturowych. Dlatego Kuciel-Frydryszak ciekawi w Iłłakowiczównie przede wszystkim to, jakie czynniki kształtowały jej charakter oraz co wpłynęło na decyzje związane z życiem prywatnym (rodzinnym) i jakie były tego konsekwencje: poświęcenie pracy urzędniczej przed II wojną światową, a po II wojnie konieczność pracy pisarskiej, która przynosiła satysfakcję w zmiennym trybie i nieregularnie. Poezja jest rozumiana dwoiście - raz jako wyraz ekspresji podmiotu, innym razem jako

14 J. Biesiada, A. Żurawska-Włoszczyńska Kazimiera Iłłakowiczówna. Bibliografia, w: K. Iłłakowiczówna Poezje zebrane, t. 4, s. 515-590.

15 J. Kuciel-Frydryszak Iłła. Opowieść o Kazimierze Iłłakowiczównie, s. 112. 
zabieranie głosu w sferze publicznej, praca przekładowa - jako praca intelektualna, praca urzędnicza - jako powołanie.

Kuciel-Frydryszak stroni przy tym od poetyki sensacyjności i daleka jest od trybu obnażania, nie pokłada zaufania w psychoanalizie. A jednak stawia mocne tezy i stosuje przy tym psychologię w wersji popularnej, podręcznej wiedzy, w której żargon naukowy stosowany jest intuicyjnie (np. nie wiemy, co rozumie przez masochizm Iłłakowiczówny - trzeba przyjąć, że chodzi o unieszczęśliwianie siebie, czyli termin z zakresu psychologicznego zagadnienia zaburzeń osobowości traktowany jest potocznie). Takie posunięcie zjednuje czytelników, którzy mogą na przemian współczuć Iłłakowiczównie i podziwiać ją, przeciwstawiając „trudny charakter” cnotom moralnym, a zarazem uszlachetnia narratorkę. Jest ona powściągliwa na takich zasadach, na których przymusza do dyskrecji sama poetka, określając sfery tabu i dostępu poprzez specyficzną konstrukcję swego archiwum oraz oficjalne wypowiedzi dla prasy. Tym samym Kuciel-Frydryszak włącza Opowieść w tradycję pisania o Iłłakowiczównie, jaki narzucała za życia oraz po śmierci sama poetka - pisania strzegącego podziału na mniej lub bardziej „ściśle tajne”. Inaczej mówiąc, nad biografią Iłły nadal ciąży „efekt przyłbicy”, wypracowana przy interpretacji Hamleta przez Jacques'a Derridę ${ }^{16}$ figura kontroli nad realizacją testamentu zmarłego, który - z całym ciężarem odpowiedzialności - ma przyjąć duchowy potomek. W przypadku Hamleta testament opierał się na długu wdzięczności i konieczności zadośćuczynienia. „Duch” Iłłakowiczówny zaś wymaga interpretacyjnych przemilczeń i biograficznej wstrzemięźliwości, a poetka - co wiadomo z książek Ratajczaka i Danielewskiej - realizuje „efekt przyłbicy” z żelazną konsekwencją - książka Kuciel-Frydryszak dowodzi, że działa on czterdzieści lat po jej śmierci" ${ }^{17}$. Historia Hamleta uczy jednak, że poddanie się kontroli ducha nie przynosi pożytku ani wykonawcy jego żądań, ani zmarłemu. Dlatego też Ratajczak ograniczył wiedzę biograficzną o poetce do minimum, stawiając na analizę podmiotu literackiego i jego utekstowionych doznań - i jako interpretator poezji Iłłakowiczówny pozostaje

16 J. Derrida Widma Marksa. Stan długu, praca żałoby i nowa Międzynarodówka, przeł. T. Załuski, PWN, Warszawa 2016.

17

Istnieje wyjątek od tej reguły: to książka Ewy Daszewskiej, której autobiograficzna narratorka mierzy się z porządkami po zmarłej krewnej i zawartością jej rodzinnego archiwum, w którym znajdują się m.in. ślady intensywnych kontaktów z poetką. Iłła jest tutaj postrzegana przez pryzmat rodziny, którą odwiedza, a w konstelacji bliskich nie stanowi centralnego obiektu zainteresowania. Takie ujęcie - decentralizujace legendę - jest odświeżające. Zob. E. Daszewska Dada, Iłła, Kika. Listy z komody, Wydawnictwo Naukowe Śląsk, Katowice 2016. 
najwnikliwszym jej czytelnikiem. Danielewska zaś uczciwie opisała swoją bezradność, niezakończony proces zmagania się z postacią „wielkiej poetessy", tyle że autokreacje Iłły zrównała z maskami Danielewskiej - lektorki, poetki, uczestniczki życia literackiego. Portrety godzin są autobiografią wpisaną w biografię na zasadzie znanej z Ścieżki obok drogi ${ }^{18}$ Iłły, mają dwie równorzędne bohaterki, z których jedna po mistrzowsku ukrywa się, a druga bezbłędnie dotyka jej najdrażliwszych punktów. Nikt tak dobrze jak Danielewska nie przeniósł na papier scen i powiedzonek stanowiących skarbnicę anegdot budujących legendę „poetki z Gajowej”.

Opowieść Kuciel-Frydryszak pisana jest pod czujnym okiem niewidocznej, ale widzącej Iłłakowiczówny, ale jednocześnie ustawia taką soczewkę narracji, aby ducha w przyłbicy odsunąć z pola widzenia. Udaje się to, ponieważ biografka dość swobodnie pisze o tym, co poetka myślała, czuła, czemu się dziwiła, co ją zaskakiwało, co wzruszało etc: jej (domniemany przecież) świat emocjonalnych reakcji niezwykle rozbudowany, mam wrażenie, że aż nadto w stosunku do surowej powściągliwości zachowanej w pamięci bliskich poetki oraz w jej tekstach autobiograficznych. Ale ten (pozorny, ale prawdopodobny) wgląd w świat wewnętrzny Iłłakowiczówny działa skutecznie i profiluje narrację. I choć diagnozy psyche autorki Szeptem wydają się rozbudowane, to nie przekraczają granic dyskrecji wyznaczonych przez poetkę - taktowność w tym zakresie jest być może niepodważalną cnotą - to niestety podobnie dzieje się z refleksją nad historią, kulturą i społeczeństwem. Powtarzając gest Iłłakowiczówny, Kuciel-Frydryszak po prostu wycisza pewne problematyczne (dla samej Iłły), lecz domagające się omówienia sprawy, przede wszystkim: kult Piłsudskiego, zaangażowanie pisarzy w politykę polsko-litewską, klasowe nierówności, równouprawnienie kobiet (a przecież i te zagadnienie dałoby się sprofilować psychologicznie - np. pisząc o psychologii władzy). Nawet kiedy Kuciel-Frydryszak nie jest równie dociekliwa i sprawiedliwa w diagnozowaniu poszczególnych elementów „życia i twórczości”, nie pozostawia ani jednego pustego kamyczka w swej mozaice. Mozaice - dodać trzeba - dającej obraz panoramiczny z najważniejszymi punktami węzłowymi: trudnym dzieciństwem, edukacją, karierą urzędniczki, emigracyjną biedą, powojennym odbudowywaniem pozycji i ciężką pracą przekładową,

18 Była to autobiografia admiratorki i pracownicy Józefa Piłsudskiego, zob. K. Iłłakowiczówna Ścieżka obok drogi, Rój Warszawa 1938; Por. M. Bednarek W cieniu Marszałka?, z Marszałkiem w tle?: narodziny dyskursu autobiograficznego Kazimiery Iłakowiczówny, w: Homo politicus: polityczne aspekty literatury, języka, teatru i filmu, red. M. Junkiert, L. Marzec, P. Michalska, A. Pytlewska, Wydawnictwo „Poznańskie Studia Polonistyczne”, Poznań 2001, s. 37-48. 
w końcu nieuleczalną chorobą i śmiercią. Sądzę jednak, że jeśli przyjmiemy, że o Iłłakowiczównie nie można pisać tego, o czym ona sama nie chciałaby, by stanowiło przedmiot publicznego zainteresowania, nie pojmiemy kulturowej wagi jej pisarstwa i nie dowiemy się więcej o świecie, który zamieszkiwała. Skupię się na trzech, pozornie odrębnych zagadnieniach (ograniczając ramy czasowe do okresu przedwojennego): „skazy” nieślubnego pochodzenia, erotyki/małżeństwa i politycznych implikacji pracy na stanowisku sekretarza Józefa Piłsudskiego, które w moim przekonaniu narracja Kuciel-Frydryszak traktuje zbyt oględnie.

Retroaktywnie odczytana pod kątem mitu pochodzenia twórczość Iłłakowiczówny świadczy o fascynacji figurą biologicznych rodziców oraz wielkiego dziadka, choć są to tropy zaszyfrowane w krypcie wstydu/dumy ${ }^{19}$, (samo)wiedzy/niewiedzy tej poezji. Cytowane przez Kuciel-Frydryszak (a wcześniej Ratajczaka i innych ${ }^{20}$ ) zdanie-refren Z rozbitego fotoplastikonu: „Barbara, nieślubna synowa promienistego Tomasza, umiera" jest najczytelniejszym fragmentem hieroglifu, oderwanym z krypty przechowującej „to, co nie powinno nigdy mieć miejsca”, czyli „nielegalnych” narodzin ze związku przekraczającego bariery stanowe, który w literackich i historycznych narracjach najczęściej znajduje jedno rozwiązanie: śmierć. Taki jest finał Trędowatej (1909), najsłynniejszego polskiego romansu międzyklasowego ${ }^{21}$, jak i historii Barbary Radziwiłłówny, inspirującej wielu twórców ${ }^{22}$, a której Iłłakowiczówna poświęciła cykl w tomie Ballady bohaterskie (1934). Uczynienie z romansu matki, ubogiej nauczycielki języków, z zamożnym i wpływowym Klemensem Zanem, wnukiem Tomasza „Promienistego”, tematu twórczości - mniej lub bardziej jawnym, ale zarazem „rymującym się" z historią polskiego króla i litewskiej ziemianki - jest nie tylko przejawem reparacyjnego autobiografizmu oraz

Odwołuję się znów do metaforyki Derridiańskiej: zob. J. Derrida Fora. „Kanciaste”słowa Nicolasa Abrahama i Márii Török, przeł. B. Brzezicka, „Teksty Drugie” 2016 nr 2.

Zob. M. Korniłowiczówna Wnuczka promienistego Tomasza (Zana), "Odra” 1983 nr 9; Rekonstrukcjom mitu pochodzenia Iłłakowiczówny są podporządkowane Portrety godzin Danielewskiej, w pewnej mierze książki Ratajczaka - nie warto ich powtarzać i cytować bibliografii. Ważniejsze jest to, jak ów mit wpłynął na formowanie się narracji biograficznych o poetce i jak wiąże się z dialektyką romantycznego powinowactwa - samorodności geniuszu poetyckiego oraz metaforyką obciążeń genetycznych. Jest to wzorzec narracji formujący wspomnienia siostry Iłły, Barbary Czerwijowskiej, które obszernie cytuje Kuciel-Frydryszak. I. Iwasiów Barbara Radziwiłówna, w: ...czterdzieści i cztery. Figury literackie. Nowy kanon, red. zbior. Wydawnictwo IBL PAN, Warszawa 2017. 
śladów mocowania się ze stygmatem pochodzenia. Świadczy przede wszystkim o celowym osadzeniu swojego życia w literaturze: jej konwencjach, kliszach, gatunkach oraz różnych modalnościach podmiotu lirycznego/autobiogarficznego/eseistycznego ${ }^{23}$. W dwóch obszarach, w których Iłłakowiczówna poruszała się sprawnie: w literaturze i dyplomacji, wybierała zawsze drogę konwencji, etykiety, szyfrując wejście do krypty-labiryntu, skrywającego wiele tajemnic osobistych, ale jednoczenie dając podpowiedzi, by niektóre z nich rozwikłać. Zignorowanie świadomości, z jaką Iłła konstruowała swoją poezję i siebie - autobiografkę, korespondentkę, urzędniczkęi kobietę-instytucję, nie pozwala na zniuansowanie wielogłosu, którym o sobie opowiadała.

Jeśli „skaza pochodzenia” ma oczywiste znaczenie dla samej Iłłakowiczówny (pisze Kuciel-Frydryszak o „zabarwionym na ciemno życiu i twórczości") i wiąże się z jej decyzjami matrymonialnymi, to przede wszystkim interesujące jest tło polityczno-ekonomiczne obydwu kwestii. W patriarchalnej i klasowej ekonomii fantazja o przekroczeniu granicy stanu i związanej z tym rozkoszy najczęściej podtrzymuje porządek prawa (zwyczajowego, nieraz wspieranego przez system - tak było w zaborze rosyjskim, gdzie nieślubne dzieci nie miały szans na państwową edukację), stojącego na straży porządku społecznego i dystrybucji władzy. Iłłakowiczówna-poetka zabierająca głos w sprawie swego pochodzenia wkrada się niejako w porządek, z którego została (działaniem rodziców i machiny społeczno-obyczajowej) wykluczona. Kuciel-Frydryszak wycisza niemal całkowicie ten wątek, który można by określić syndromem Kopciuszka, Kopciuszka, który dostaje się na bal jako Nowa Kobieta: wykształcona singielka, urzędniczka państwowa, w końcu sekretarz Piłsudskiego i „wielka dama” poezji dwudziestolecia. Pragnienie niemożliwego dla matki poetki awansu społecznego (z jego fantazmatem miłości przekraczającej granice klasowe) przynależy do odchodzącej po I wojnie światowej wraz z „długim wiekiem dziewiętnastym” formacji kulturowej, wygasającej jednak niezwykle powoli, na przekór wysiłkom konserwatywnych polityków oraz przyzwyczajeniom arystokracji i ziemiaństwa. Obok poczucia krzywdy i wstydu, o których wspomina z empatią Kuciel-Frydryszak, Iłłakowiczówna dawała wyraz bezwstydu i dumy ze zdobytej przez siebie pozycji społecznej, o czym wspominają niejednokrotnie Łucja Danielewska w swoich Portretach godzin i pamiętnikarze epoki. To właśnie poezja dała klucz

23 Por. analizy literackich biografii kobiet z perspektywy feministycznej standpoint theory Nancy Harstock, uwypuklające "awans i degradację przez miłość", K. Szumlewicz Miłość i ekonomia w literackich biografiach kobiet, Wydawnictwo IBL PAN, Warszawa 2017. 
do innego, niż małżeństwo, prestiżu i otworzyła inną, niż praca, sferę emancypacji. Stawała się (od połowy XIX wieku) dla kobiet i dla warstw niższych coraz dostępniejsza jako forma aktywnego życia publicznego i awansu społecznego: syn organisty otrzymuje literacką Nagrodę Nobla, Zofia Nałkowska (bezdzietna, rozwiedziona) zasiada pośród najwybitniejszych w Polskiej Akademii Literatury. Jeśli niepewny status społeczny wykluczył Iłłakowiczównę z rynku matrymonialnego (ale nie erotycznego) warstwy, którą się otaczała, a praca zarobkowa była w jej przypadku życiową koniecznością, i jeśli odczuwała swoje nieślubne pochodzenie jako piętno, to poezja pozwoliła jej o tej krzywdzie opowiadać, publicznie rozważać, przypominać o niej. Oczywiście tylko na pewnych warunkach, które ambitna poetka wypełniła bez zarzutu, nawet kosztem wewnętrznej szamotaniny i wyborów gatunkowych i tematycznych. To przecież nie przypadek ani zbieg okoliczności, że ta sama osoba zostaje nagrodzona prestiżowymi nagrodami państwowymi za działalność literacką i dyplomatyczną, że w przemówieniach dyplomatycznych na rzecz propagandy Polski wyznaje, że jest przede wszystkim poetką, a w wywiadach dla pism literackich umniejsza swe pisarstwo i uwzniośla urząd; że w wykładzie na Kongresie Kobiet z Wyższym Wykształceniem milczy o dyskryminacji płciowej w MSZ czy równouprawnieniu, proponując pogadankę „O niczem”, wychwalającą wypoczynek na łonie przyrody... Wyjaśnienia psychologizujące - takich w przypadku biografii Iłły najwięcej - przesadnie podkreślają kapryśny charakter czy przekorną dumę, czyli cechy osobowościowe, ignorując przenikanie się dwóch prestiżów - laurów poetyckich i odznaczeń państwowych - tworzących ramy zarówno dla poezji, jak i dla publicznej działalności Iłłakowiczówny.

Po trzecie wreszcie Kuciel-Frydryszak całkowicie pomija kwestię, która dla biografii stanowi sprawę istotną, zwłaszcza w książce tak psychologicznie sprofilowanej i nakłada się na wątki, które omówiłam: chodzi o życie erotyczne Iłłakowiczówny i jej doświadczenie niespełnionego macierzyństwa oraz straty dziecka. To zagadnienie było dla wcześniejszych biografów rejonem ściśle tajnym - i nadal nim pozostaje, przenosząc w XXI wiek normy obyczajowe samej poetki i czyniąc książkę nieco anachroniczną, jeszcze bardziej niż była erotyka poezji Iłłakowiczówny porównana z erotyką Marii Pawlikowskiej-Jasnorzewskiej (a musiała taka być właśnie dlatego, że Iłła pracowała w urzędzie i jako singielka, jej intymne wiersze i sprawy - były tematem publicznym). Oczywiście poetka nie pozostawiła żadnych jednoznacznych śladów swojego życia intymnego. Legenda o odrzuconych oświadczynach hrabiego, zdawkowe informacje z listów o dawnych sympatiach, w końcu 
poezja - w kilku tomach całkowicie niemal skupiona na kwestii utraty i kochanka, i dziecka - są kontekstem, z którego nie warto czynić dowodów w sprawie. Ale właśnie sekretność owego obszaru należałoby ustanowić tematem zainteresowania, bo tajemnice Iłłakowiczówny nie świadczą tylko o kształcie i zawartości jej krypty (rezygnacja z małżeństwa jako „wariacja” nt. losu matki, tyleż świadoma co nieświadoma zemsta, która obraca się przeciw rycerce - równoległe wobec „Hamleta” tropy narzucają się natrętnie), ale przede wszystkim mówią o splocie prywatnego i publicznego w konkretnym momencie historycznym. Brakowało mi w Opowieści... odpowiedzi na pytanie, czym było nieślubne macierzyństwo w dwudziestoleciu i co oznaczało małżeństwo dla urzędniczki państwowej. Tylko obok dyskusji wokół „świadomego macierzyństwa" Ireny Krzywickiej i Boya z jednej strony - a z drugiej w odczuwanych na własnej skórze prawnych i obyczajowych wykluczeń (zamężne urzędniczki państwowe były zagrożone zwolnieniami ze względu na bezrobocie mężczyzn; samotne matki traciły pracę i źródło utrzymania, nie działał system alimentacyjny etc.) można uzmysłowić sobie wahadłowy ruch tej poezji (i szerzej twórczości) między polityczną służbą, moralnymi powinnościami, ustanawianiem i podtrzymywaniem prestiżu, a swobodą wypowiedzi w sprawach newralgicznych na planie publicznym i prywatnym. Dzięki temu pojmie się ponadindywidualne wartości żałobnych wierszy o "główkach dziecięcych”, a „młodopolskość” czy „staroświeckość” poezji Iłły ujawni się jako maska dla wypowiedzenia doświadczeń granicznych i kompromis konieczny dla podtrzymania wysokiego statusu (Iłłakowiczówna, jak wielu, przebyła swoją „walkę o sławę") ${ }^{\mathbf{2 4}}$. Kuciel-Frydryszak wybiera inną drogę: omawia intymne relacje Iłłakowiczówny z mężczyznami, powołując się przede wszystkim na wyznania podmiotu lirycznego poezji, ale znów tylko pozornie w ten sposób przekraczając próg dyskrecji. Moje wątpliwości wzbudza użycie utworów z cyklu Lew (z tomu Śmierć Feniksa, 1922), które interpretowane są wybiórczo i poza kontekstem całości. Ostatecznie można uznać każde wyznanie liryczne jako wyraz ekspresji „ja” poetki (choć wymagałoby to pewnego komentarza, a najlepiej metodologii psychoanalitycznej, np. takiej, jaką praktykuje Lena Magnone w przypadku Marii Konopnickiejej), jednak diabeł tkwi w szczegółach. Kuciel-Frydryszak cytuje kilka wersów

\footnotetext{
24 A jednocześnie inna droga do kanonu niż w przypadku XX-wiecznych klasyczek, o których pisze Monika Świerkosz. Zob. M. Świerkosz Arachne i Atena. Literatura, polityka i kobiecy klasycyzm, Wydawnictwo UJ, Kraków 2017. 
i zapytuje retorycznie, czy są to „odważne jak na ów czas marzenia-rojenia wyemancypowanej kobiety. Nie mąż, rodzina i dom, tylko dochodzący kochanek - czy tego by chciała dla siebie?"26. Być może. Tylko że cytowany utwór jest komentarzem drwiącym z mieszczańskich schematów życia. Potencjalnemu ustatkowaniu z „grubym bankierem” w „ślicznych krawatach”, którego Frydryszak widzi jako dochodzącego kochanka - „ja” liryczne przeciwstawia namiętność wykraczającą poza granice (i tu już tekst otwiera się na wielość interpretacji: klasowe, obyczajowe, etnicznie, gatunkowe) łączącą ją z lwem, niebezpiecznym dla otoczenia zwierzęciem, z którym umawia się na schadzki. Wyrwane z kontekstu strofy „I jeszcze co będę miała”, będące statycznym wyliczeniem dobytku zamożnej mieszczanki, nie tyle podważają interpretację Kuciel-Frydryszak, co dają mylny obraz kreowanego w liryce międzywojennej Iłły podmiotu kobiecego (i być może nawet samej autorki). Niestety w Opowieści nieumiejętne dobieranie cytatów z twórczości poetki osłabia najciekawsze interpretacje i ważne dla badań literaturoznawczych sugestie, działając na niekorzyść książki.

Polemizuję silnie z sądami Kuciel-Frydryszak, ponieważ jestem przekonana, że zarówno biografia, jak i twórczość Iłłakowiczówny domagają się reinterpretacji. Nie warto ufać duchowi w przyłbicy, nie warto mu służyć jeśli duch ma tendencje masochistyczne, będzie działał na swoją niekorzyść i na zgubę innych. Chociażby dlatego, że apolityczność poetki to mit, którego nie warto podtrzymywać ${ }^{27}$. Warto natomiast pokazać, i w jakich warunkach się wytwarzał, dlaczego był konieczny i co, dzięki tej jednej z wielu masek poetki-instytucji Iłłakowiczówna straciła, a co zyskała. Na skutek poruszeń społeczno-politycznych, i jej (a)polityczność przemieszczała się bowiem w różne obszary. Rozwiązanie połowiczne, które proponuje Kuciel-Frydryszak, nie pozwala przekroczyć zwyczajowego spojrzenia na zagadnienie: "poetka a urzędniczka". Jest ono istotne nie tylko dla dopełnienia portretu autorki Stowika litewskiego, ale także (a może przede wszystkim) dla obrazu

26 J. Kuciel-Frydryszak Iłła. Opowieść..., S. 128.

27 Por. refleksje M. Rudaś-Grodzkiej nad spotkaniem widma w archiwum, które, choć podążają w inną niż tu zaprezentowana, stronę (badaczka mówi o potencjalnym spotkaniu z widmem i „mgławicowej substancjalizacji” widma w osobie badaczki, co do którego mam wątpliwości), to silnie akcentują niszczycielską rolę legend i mitów: „Prawdziwą siłą destrukcyjną jest mit, który w połączeniu z historią wytwarza prawdziwą zasłonę dymną duszącą rzeczywistych aktorów dziejów, pozbawia ich możliwości wypowiadania się w swoim imieniu, z drugiej zaś strony otumania badaczy przeszłości". M. Rudaś-Grodzka Biografia więzienna, w: B. Waligórska Listy z Cytadeli 1886, Wydawnictwo IBL PAN, Warszawa 2018, s. 23. 
międzywojennego i powojennego życia literackiego wraz z jego instytucjami (nagrodami, PAU, PAL,ZLP, spolaryzowanym ideowo czasopiśmiennictwem, cenzurą, wydawnictwami) - w relacji wobec kulturalnej polityki państwowej, rynku książki i tego wszystkiego, co tworzy pole literatury.

\section{Abstract}

\section{Lucyna Marzec}

ADAM MICKIEWICZ UNIVERSITY (POZNAŃ)

Biography from behind a Visor: Kazimiera Iłłakowiczówna According to Joanna Kuciel-Frydryszak

Review: J. Kuciel-Frydryszak, Iła: Opowieść o Kazimierze Iłłakowiczównie [1ła: A Tale about Kazimiera Iłakowiczówna], Marginesy, Warsaw 2017.

\section{Keywords}

life writing, archive, literary biography, Iłakowiczówna, Kuciel-Frydryszak 